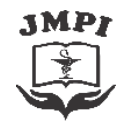

Jurnal Mandala Pharmacon Indonesia, Vol 7.No.1 Juni 2021

Avaiable online at www.jurnal-pharmaconmw.com/jmpi

$p$-ISSN : 2442-6032

e-ISSN : 2598-9979

\title{
Formulasi dan Karakterisasi Nanopartikel Kafein Hasil Isolasi dari Biji Kopi Robusta (Coffea canephora var. Robusta)
}

\author{
Yunida ${ }^{1}$, Muhammad Totong Kamaluddin ${ }^{2}$, Theodorus 3 , Sonlimar Mangunsong 4 \\ 1Program Studi Biomedik, Fakultas Kedokteran Universitas Sriwijaya \\ ${ }^{2}$ Departemen Farmakologi, Fakultas Kedokteran Universitas Sriwijaya \\ 3Jurusan Farmasi, Politeknik Kesehatan Kementerian Kesehatan Palembang
}

\begin{abstract}
ABSTRAK
Kopi robusta merupakan jenis kopi yang paling banyak dikembangkan oleh petani di Indonesia. Kopi kaya akan zat bioaktif yang memberikan manfaat bagi kesehatan, salah satunya adalah kafein. Namun, konsumsi kafein dalam jumlah berlebihan juga dapat menimbulkan efek samping.. Salah satu upaya untuk meminimalkan efek samping dan menghasilkan sediaan sustained release adalah dengan membuat formulasi kafein dalam bentuk sediaan nanopartikel. Dalam penelitian ini dilakukan ekstraksi, isolasi dan identifikasi kafein dari biji kopi robusta. Dari 200 gram biji kopi robusta diperoleh

nanopartikel kafein dilakukan menggunakan metode single emulsion-solvent evaporation dengan pembawa PLGA (Poly-(Lactic-co-Glycolic Acid)) dan PVA (Poly(Vinyl Alcohol)) sebagai stabilizer. Karakterisasi preparat nanopartikel menggunakan PSA (Particle Size Analyzer) dengan $2 \mathrm{x}$ pengulangan memberikan hasil diameter ukuran partikel 183,9 nm dan 184,7 nm, nilai PDI (Polydispersity Index) 0,113 dan 0,182, zeta potensial -13,5 mVdan -12,8. Penentuan morfologi menggunakan Transmission Electron Microscopy diperoleh partikel yang berbentuk bulat (spheris).
\end{abstract} kristal kafein sebanyak o,83 gram. Hasil identifikasi secara mikroskopis diperoleh morfologi kristal kafein seperti jarum-jarum panjang dan karakteristik kristal kafein mirip dengan kafein standar. Preparasi

Kata kunci : kopi robusta, kafein, formulasi, nanopartikel

\begin{abstract}
Robusta coffee is the type of coffee that is mostly developed by farmers in Indonesia. Coffee is rich in bioactive substances that provide health benefits, one of which is caffeine. However, excessive consumption of caffeine can also cause side effects. One of the efforts to minimize side effects and produce sustained release preparations is to make caffeine formulations in the form of nanoparticles. In this study, extraction, isolation and identification of caffeine from robusta coffee beans was carried out. From 200 grams of robusta coffee beans obtained caffeine crystals as much as 0.83 grams.

preparation of caffeine nanoparticles was carried out using the single emulsion-solvent evaporation method with PLGA (Poly-(Lactic-co-Glycolic Acid)) and PVA (Poly-(Vinyl Alcohol)) carriers as stabilizers. The characterization of nanoparticle preparations using PSA (Particle Size Analyzer) with $2 \times$ repetitions gave the results of particle size diameters of $183.9 \mathrm{~nm}$ and 184.7 $\mathrm{nm}$, PDI (Polydispersity Index) values of 0.113 and o.182, zeta potential $-13.5 \mathrm{mV}$ and -12.8 . Morphological determination using Transmission Electron Microscopy obtained spherical particles.
\end{abstract} Microscopic identification results obtained caffeine crystal morphology such as long needles and caffeine crystal characteristics similar to standard caffeine. The
Keywords: robusta coffee, caffeine, formulation, nanoparticles.

\author{
Penulis Korespondensi : \\ Yunida \\ Program Studi Biomedik, Fakultas Kedokteran, \\ Universitas Sriwijaya \\ Email : yunidasimanjuntak21@gmail.com
}

\section{Informasi Artikel}

$\begin{array}{ll}\text { Submitted } & : 25 \text { April } 2021 \\ \text { Accepted } & : \text { 23 Juni } 2021 \\ \text { Published } & : \text { 30 Juni } 2021\end{array}$




\section{PENDAHULUAN}

Indonesia memiliki kopi dengan kualitas yang beragam mulai dari kopi kualitas rendah sampai kualitas terbaik. Kopi merupakan tanaman perdu yang termasuk dalam famili Rubiaceae dan genus Coffea. Secara umum ada dua jenis kopi yaitu Coffea arabica dan Coffea canephora yang masing-masing dikenal sebagai kopi varietas arabika dan robusta. Kopi arabika tumbuh pada ketinggian di atas $1000 \mathrm{~m}$ dpl. Namun, lahan tanam kopi yang tersedia di Indonesia sampai saat ini sebagian besar berada di ketinggian antara 700 sampai $900 \mathrm{~m} \mathrm{dpl.}$ Mungkin hal ini yang menyebabkan mengapa sebagian besar (sekitar 95\%) jenis kopi di Indonesia saat ini adalah kopi robusta (Nurdiansyah, 2014).

Kopi arabika terdapat di Aceh dan Sumatera Utara. Kopi robusta tersebar di hampir seluruh kepulauan Indonesia yaitu Sumatera, Jawa, Nusa Tenggara dan Bali. Sisanya terdapat di Kalimantan, Sulawesi dan Maluku/Papua. Kopi robusta (Coffea canephora var. Robusta) memiliki kandungan komponen bioaktif seperti kafein yang lebih tinggi dibandingkan kopi arabika, kopi robusta juga adalah spesies kopi yang dapat beradaptasi dengan baik pada dataran rendah dengan kondisi hangat dan lembab serta lebih tahan terhadap penyakit dan hama (Goldemberg et al., 2014).

Kopi adalah sumber utama kafein dan kafein merupakan senyawa yang secara luas dikonsumsi setiap hari oleh manusia. Kafein banyak digunakan dalam berbagai minuman ringan sebagai penambah cita rasa dan dalam bentuk kombinasi dengan obat-obatan seperti aspirin, asetaminofen, ergotamine sebagai penghilang rasa sakit (Chaugule et al., 2019). Kafein adalah alkaloid yang terbentuk secara alami, dapat ditemukan setidaknya pada 63 spesies tanaman dan terdapat pada daun, biji dan buah. Kandungan kafein bervariasi sesuai dengan spesies dan asal tanaman (Ahmad Bhawani et al., 2015).

Kafein termasuk dalam kelompok senyawa xanthin alami dan mungkin adalah senyawa stimulan tertua (Bhawani, et al., 2015). Konsumsi kafein dapat memicu kewaspadaan, gairah, memperbaiki mood dan menyebabkan pelepasan katekolamin yang akan menyebabkan efek menguntungkan pada perilaku manusia (Andrén-Sandberg, 2016). Manfaat kafein bagi kesehatan : kafein dapat membantu melindungi selsel otak manusia, yang menurunkan risiko berkembangnya penyakit seperti parkinson, secangkir kopi setiap hari dapat merangsang kantung empedu dan mengurangi risiko batu empedu, kafein menyebabkan vasokonstriksi pembuluh darah, yang dapat membantu meredakan sakit kepala, kopi dapat mengurangi peradangan dan dapat membantu mencegah penyakit tertentu yang berkaitan dengan jantung, mengobati 
migrain, meredakan serangan asma, meningkatkan potensi obat analgesik, krim kafein digunakan secara topikal untuk mengurangi kemerahan dan gatal pada dermatitis (Chaugule et al., 2019).

Kadar kafein sangat bervariasi tergantung pada apa yang dikonsumsi. Sepotong coklat mungkin mengandung kafein sedikitnya 5 miligram sedangkan minuman berenergi mengandung kafein sebanyak 160 miligram (Chaugule et al., 2019). Kafein dapat menimbulkan berbagai efek samping apabila dikonsumsi dalam jumlah yang berlebihan seperti anxiogenic-like effect, takikardia dan aritmia, kafein juga menstimulasi sekresi asam lambung. Pasien yang menderita peptic-ulcer disease disarankan untuk tidak mengkonsumsi kopi. Menurut SNI 01-7152-2006 batas maksimum kafein dalam makanan dan minuman adalah 150 $\mathrm{mg} /$ hari dan $50 \mathrm{mg} / \mathrm{sajian}$ ((Zarwinda \& Sartika, 2019).

Nanopartikel dalam ilmu farmasi digunakan dengan tujuan untuk mengurangi toksisitas dan meminimalkan efek samping obat dengan menargetkan kerja obat pada site of action yang spesifik, mengurangi dosis dengan adanya perubahan pada parameter farmakokinetik, mengurangi frekuensi pemberian dosis dengan mengontrol pelepasan obat dan meningkatkan shelf life dengan adanya perbaikan pada stabilitas sediaan (Raval et al., 2018).
Nanoteknologi mendapat banyak perhatian dalam industri farmasi, secara khusus dalam sistem penghantaran obat (drug delivery) (Raval et al., 2018). Nanopartikel dapat dimanfaatkan dalam sistem penghantaran topikal, transdermal, oral maupun parenteral (Jia, L., 2005). Nanopartikel merupakan partikel koloid polimer dengan ukuran sub-mikron (berkisar 10-1000 nm) dengan satu atau lebih zat aktif yang dienkapsulasi, diabsorpsi atau dijerap pada permukaan matriks polimer (Castro \& Kumar, 2013).

Peneliti akan melakukan ekstraksi kafein dari kopi robusta (Coffea canephora var. Robusta) dan modifikasi preparat kafein sebagai upaya untuk memperoleh sediaan sustained release serta meningkatkan waktu paruh kafein, yaitu dengan membuat preparat nanopartikel kafein dalam bentuk submikro partikel (200-600 nm) menggunakan PLGA dan PVA.

Poly (lactic-co-glycolic acid) (PLGA) adalah salah satu biodegradable, biocompatible polymers yang paling berhasil penggunaannya dalam pengembangan sediaan mikro atau nanopartikel dan telah disetujui FDA. Merupakan polimer serba guna dikarenakan pemilihannya dapat disesuaikan dengan kebutuhan berdasarkan berat molekul, copolymerization dan fungsi yang diperlukan. Kelebihan utama PLGA 
adalah akan terhidrolisis menjadi metabolit monomer yaitu lactic acid dan glycolic acid. Kedua monomer endogen ini akan dimetabolisme tubuh dengan mudah melalui siklus Krebs, sehingga meminimalkan toksisitas sistemik pada penggunaannya sebagai pembawa obat atau aplikasi lainnya dalam bidang biomaterial (Danhier et al., 2012).

Pada penelitian ini PVA (poly-(vinyl alcohol)) sebagai surfaktan yang mengacu pada penelitian Mardiyanto et al., (2018). Penentuan konsentrasi PLGA sebanyak $100 \mathrm{mg}$ mengacu pada penelitian (Sidiq, 2018), jumlah PVA yang digunakan sebanyak $50 \mathrm{mg}$ dan waktu sonikasi selama 10 menit berdasarkan pada penelitian Mardiyanto et al., (2018).

Tujuan dari penelitian ini adalah untuk mengisolasi dan mengidentifikasi kafein dari biji kopi robusta, serta formulasi dan karakterisasi preparat nanopartikel kafein menggunakan PSA (Particle Size Analyzer) dan TEM (Transmission Electron Microscopy).

\section{METODE PENELITIAN}

Penelitian ini menggunakan desain eksperimental bersifat deskriptif yang memberikan gambaran umum mengenai karakteristik kristal kafein dari biji kopi robusta dan karakterisasi preparat nanopartikel kafein dari sampel kopi tersebut.

\section{A. Bahan dan Alat}

1. Bahan

Bahan yang digunakan dalam penelitian ini : biji kopi robusta, kafein murni (Brataco), natrium karbonat/ $\mathrm{Na}_{2} \mathrm{CO}_{3}$ (Merck), Plat KLT Al Silika Gel GF 254 (Merck), PLGA dan PVA (Sigma Aldrich) serta beberapa pelarut dengan kualitas p.a dari Merck dan pelarut teknis dari Bratachem.

\section{Alat}

Alat yang digunakan : Hot plate (Thermo Scientific), magnetic stirrer, neraca analitik (Matrix AJ302B), neraca analitik (Shimadzu AUW 220), kertas saring, tisu, rotary evaporator (IKA RV 10), plat KLT (silika gel F254) (Merck), bath sonicator (Bransonic 1510E-MT), mikroskop (Olympus) dan alat-alat gelas yang menunjang penelitian seperti : Erlenmeyer (Iwaki), batang pengaduk, pipet tetes, corong (Iwaki), gelas ukur (Iwaki), corong pisah (Iwaki), cawan porselen, termometer (Alla France), mikropipet (Ecopipette).

\section{B. Prosedur}

1. Pengambilan Sampel Biji Kopi Robusta

Biji kopi robusta diperoleh dari petani kopi. Biji kopi dijemur dan dikeringkan dan disimpan dalam wadah kedap udara yang tertutup rapat.

2. Ekstraksi Kafein

Sampel yang telah dihaluskan sejumlah 200 gram dimasukkan ke dalam 
labu Erlenmeyer, ditambahkan aquadest $1000 \mathrm{ml}$, dipanaskan hingga mendidih, diidiamkan sebentar, disaring. Pada filtrat ditambahkan natrium karbonat sebanyak 20 gram, kemudian dipanaskan hingga setengah campuran, didinginkan, disaring menggunakan kertas saring (Suwiyarsa et al., 2018). Filtrat dimasukkan dalam corong pisah. Dilakukan ekstraksi cair cair menggunakan pelarut semipolar etil asetat sebanyak $100 \mathrm{ml}$ dengan pengulangan sebanyak 3 kali. Lapisan etil asetat dikumpulkan, diuapkan pada rotary evaporator sehingga diperoleh ekstrak cair hasil fraksinasi (Wilantari, 2018).

3. Purifikasi Kafein dengan Metode Kristalisasi

Ditambahkan aseton sebanyak 10 ml pada padatan kering hasil fraksinasi, kemudian disaring dengan kertas saring. Diuapkan larutan aseton dengan hati-hati pada suhu $56^{\circ} \mathrm{C}$, maka perlahan aseton akan menguap (Wilantari, 2018). Terbentuk kristal kafein pada dasar cawan porselen yang berbentuk seperti jarumjarum panjang (Sarfraz et al., 2012).

4. Identifikasi Kristal Kafein

a. Identifikasi morfologi kristal kafein hasil purifikasi menggunakan pewarna safranin.

b. Identifikasi kristal kafein dengan pereaksi kristal $\mathrm{FeCl}_{3}$ 20\%. Kafein diletakkan pada objek glass, diteteskan $\mathrm{FeCl}_{3}$ 20\%, dibuat pembanding $\mathrm{FeCl}_{3}$ sebagai blanko. Dibiarkan hingga mengering, tutup dengan cover glass, preparat yang dibuat dilihat di bawah mikroskop dengan perbesaran $40 \mathrm{x}$.

\section{Nanopartikel Kafein}

\section{a. Preparasi Polimer dan Kafein} PVA dilarutkan ke dalam aquadest pada suhu $70^{\circ} \mathrm{C}$. Homogenisasi PVA dilakukan menggunakan magnetic stirrer dengan kecepatan 100 rpm selama 24 jam hingga menunjukkan larutan yang homogen. PLGA dilarutkan ke dalam etil asetat, dihomogenkan menggunakan stirrer dengan kecepatan 100 rpm pada suhu kamar selama 4 jam. Serbuk kafein ditimbang dan dilarutkan dengan etil asetat (fase pendispersi) di dalam vial, lalu homogenkan dengan kecepatan 100 rpm selama 4 jam menggunakan magnetic stirrer pada suhu kamar, kemudian didiamkan hingga larut (Mardiyanto et al., 2018).

b. Pembuatan nanopartikel PLGA-kafein dilakukan menggunakan metode emulsion-solvent evaporation. Sejumlah $2 \mathrm{~mL}$ larutan yang mengandung $50 \quad \mathrm{mg}$ kafein dicampurkan dengan larutan $100 \mathrm{mg}$ PLGA sebanyak 2,5 mL menggunakan magnetic stirrer (fase minyak) dengan kecepatan 750 rpm sebagai massa 1. Adapun sebagai massa 2 yaitu larutan PVA (fase air), dihomogenkan dengan magnetic stirrer pada kecepatan 750 rpm, dipipet sebanyak $2 \mathrm{~mL}$ yang mengandung $50 \mathrm{mg}$ PVA. Emulsifikasi dilakukan antara massa 1 dan massa 2 
dengan cara penetesan menggunakan pipet mikro (emulsi $\mathrm{O} / \mathrm{W}$ ) di atas magnetic stirrer. Proses emulsifikasi tersebut menggunakan kecepatan 750 rpm selama 1 jam. Larutan kemudian dihomogenkan menggunakan bath sonicator dengan frekuensi $42 \mathrm{kHz}$ selama 10 menit. Penambahan aquadest ad $25 \mathrm{~mL}$ dilakukan untuk mengencerkan larutan partikel. Untuk menghilangkan sisa pelarut organik maka larutan partikel diuapkan di atas magnetic stirrer selama 24 jam (Mardiyanto et al., 2018).

6. Karakterisasi Nanopartikel Menggunakan PSA dan TEM

a. Penentuan Diameter, PDI, dan Zeta Potensial

Alat yang digunakan dalam pengujian ini yaitu PSA merek Horiba SZ-10o melalui metode dynamic light scattering (DLS). Suspensi partikel PLGA pembawa kafein diambil sebanyak $50 \mu \mathrm{L}$ dan diencerkan dengan perbandingan $1: 100$ menggunakan aquadest. Sebanyak 50 $\mu \mathrm{L}$ dimasukkan ke dalam kuvet PSA, selanjutnya instrumen akan menembakkan cahaya monokromatik dan ditangkap oleh detektor untuk menghasilkan diameter, PDI, dan zeta potensial (Mardiyanto et al., 2018).

b. Penentuan Morfologi Partikel

Penentuan bentuk/morfologi partikel dianalisis menggunakan alat
TEM Jeol jem-1010, 80.0 KV, perbesaran $50.000 \mathrm{x}$.

\section{HASIL DAN PEMBAHASAN}

Berdasarkan hasil penelitian Putri (2015) tentang pengaruh suhu dan waktu ekstraksi terhadap kadar kafein dalam teh hitam, kadar kafein tertinggi ditemukan pada suhu ekstraksi tertinggi yaitu $100^{\circ} \mathrm{C}$ (Zarwinda \& Sartika, 2019). Oleh karena itu, pada penelitian ini ekstraksi kafein dilakukan dengan air mendidih karena kafein larut dengan baik dalam air mendidih (dePaula \& Farah, 2019). Dalam ekstrak air tidak hanya mengandung kafein tetapi terdapat pula senyawa lain yang ikut terekstraksi terutama senyawa tanin. Penambahan natrium karbonat yang bersifat basa bertujuan untuk mengubah senyawa tanin menjadi garam. Dengan mengubah tanin menjadi garamnya maka tanin akan berubah menjadi anion fenolik yang larut dalam air tetapi tidak larut dalam etil asetat. Penggunaan etil asetat karena kafein larut dalam etil asetat dan etil asetat tidak bersifat toksik (Wilantari, 2018).

Kristalisasi adalah suatu teknik pemurnian. Kristalisasi dapat didefinisikan sebagai tahap perubahan dimana produk yang berupa kristal diperoleh dari suatu larutan multi komponen yang membentuk fase tunggal homogen. Syarat suatu larutan agar dapat mengkristalisasi adalah larutan telah 
mencapai lewat jenuh. Cara yang dapat dilakukan untuk mencapai kondisi lewat jenuh tersebut diantaranya dengan perubahan temperatur dan penguapan pelarut (Fauziah et al., 2017). Dalam penelitian ini dilakukan pemurnian kafein dengan perubahan temperatur dan penguapan pelarut aseton. Hasil yang diperoleh adalah sebagai berikut :

Tabel 1. Hasil Purifikasi Kristal Kafein

\begin{tabular}{cc}
\hline $\begin{array}{c}\text { Berat fraksi etil asetat } \\
\text { (g) }\end{array}$ & $\begin{array}{c}\text { Berat kristal } \\
\text { kafein }(\mathbf{g})\end{array}$ \\
\hline 1,17 & 0,83
\end{tabular}

Catatan : dalam purifikasi tidak dilakukan proses replikasi

Gambaran kristal kafein dilihat menggunakan mikroskop :

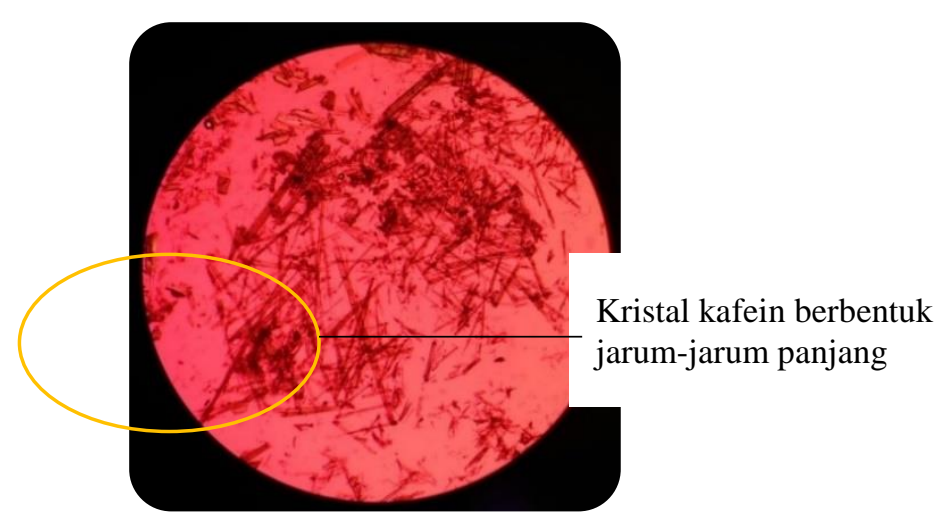

Gambar 1. Kristal kafein hasil purifikasi dengan pewarna safranin, Sumber : Dokumentasi Pribadi, 2021

Dari hasil pengamatan, diperoleh gambaran kristal kafein berbentuk jarumjarum panjang. Menurut Safraz et al., (2012) dari banyak penelitian mengenai kafein, kristal kafein paling sering ditemukan dalam bentuk jarum-jarum memanjang. Hasil yang diperoleh dalam penelitian ini sesuai dengan karakteristik kristal kafein yang disebutkan dalam literatur tersebut. Dapat disimpulkan bahwa hasil yang diperoleh adalah kafein.

Hasil identifikasi kristal kafein menggunakan pereaksi $\mathrm{FeCl}_{3}$ : 


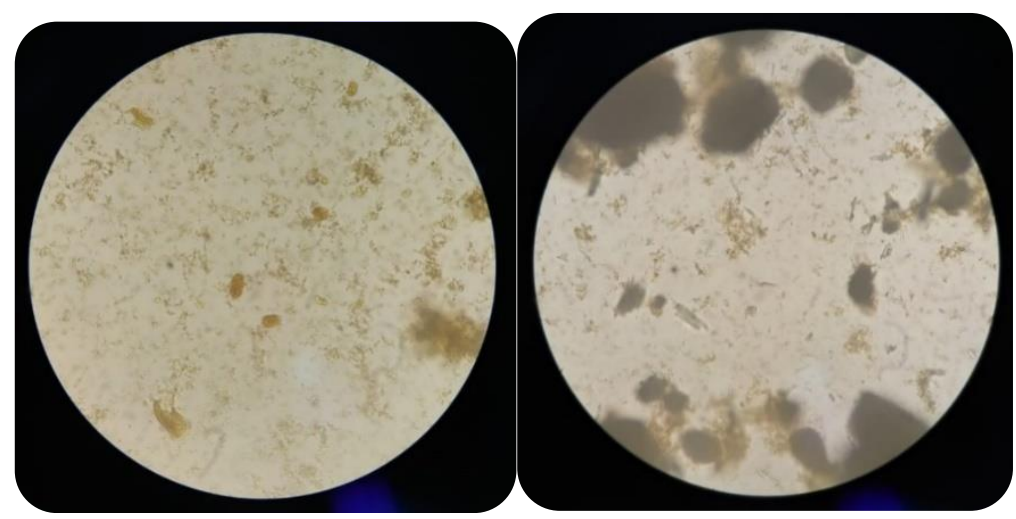

(a)

(b)

Gambar 2. (a) Kafein sampel dengan pereaksi $\mathrm{FeCl}_{3}$ (b) Kafein standar dengan pereaksi $\mathrm{FeCl}_{3}$

Sumber : Dokumentasi Pribadi, 2021

Tabel 2. Hasil Karakterisasi Formula Nanopartikel Kafein dengan PSA

\begin{tabular}{cccc}
\hline Karakterisasi & Replikasi 1 & Replikasi 2 & Rerata \\
\hline Diameter partikel (nm) & 183,9 & 184,7 & $184,3 \pm 0,565$ \\
PDI & 0,113 & 0,182 & $0,1475 \pm 0,048$ \\
Zeta Potensial (mV) & $-13,5$ & $-12,8$ & $-13,15 \pm 0,494$ \\
\hline
\end{tabular}

Hasil Penentuan Morfologi Partikel Menggunakan TEM :

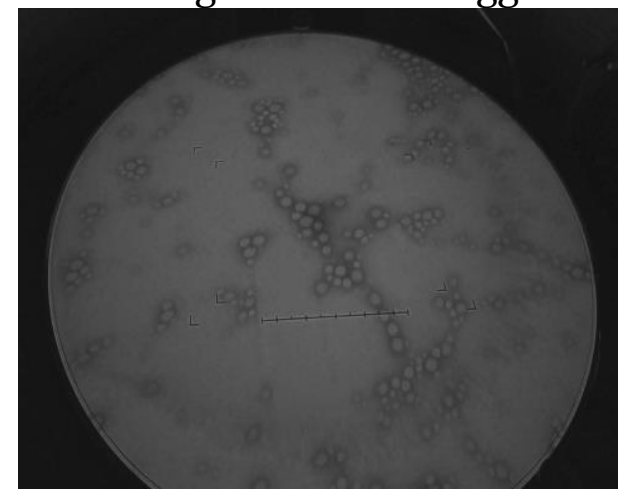

Gambar 3. Morfologi Nanopartikel Kafein dengan pembawa PLGA TEM Jeol jem-1010, 80.0 KV, perbesaran 50.000 x Sumber : Dokumentasi Pribadi, 2021

Karakteristik kristal kafein sampel mirip dengan kafein standar. Dapat disimpulkan bahwa hasil yang diperoleh adalah kafein. Diameter dan distribusi partikel merupakan parameter penting dalam karakteristik nanopartikel. Ukuran partikel adalah salah satu faktor yang mempengaruhi efisiensi nanopartikel. Parameter ini menentukan apakah sediaan nanopartikel dapat menembus berbagai membran biologi seperti sawar darah otak. Ukuran partikel juga berguna untuk memprediksi biodistribusi dan akumulasi di berbagai jaringan (FonsecaGomes et al., 2020). Diameter kapiler darah terkecil yang ada di tubuh manusia adalah sekitar $4 \mu \mathrm{m}$. Oleh karena itu, agar partikel nano dapat menjangkau semua 
lokasi tubuh, diameter partikel harusmenjadi lebih kecil (Raval et al., 2018).

Menurut Fonseca-Gomes et al., (2020) $200 \mathrm{~nm}$ adalah ukuran maksimum partikel yang dapat menembus hampir seluruh membran biologi dalam tubuh. Dari hasil karakterisasi menggunakan PSA dengan 2 kali pengulangan, diperoleh nilai diameter ukuran partikel 183,9 nm dan $184,7 \mathrm{~nm}$. Artinya preparat nanopartikel kafein dalam percobaan ini memiliki ukuran partikel yang masuk dalam kisaran yang dipersyaratkan.

Distribusi ukuran partikel diamati melalui nilai polidispersity index (PDI). Istilah "polidispersitas" (atau "dispersitas" seperti yang direkomendasikan oleh IUPAC) digunakan untuk menggambarkan tingkat ketidakseragaman distribusi ukuran partikel (Zhuang et al., 2016). Nilai PDI yang semakin mendekati o (nol) maka distribusi ukuran partikel semakin seragam. Menurut Danaei et al., (2018) nilai PDI $<0,2$ dianggap nilai yang paling dapat diterima untuk nanopartikel berbahan dasar polimer. Pada penelitian ini nilai PDI yang diperoleh dari 2 kali pengulangan adalah 0,113 dan 0,182. Artinya bahwa partikel memiliki distribusi ukuran yang seragam (monodisperse). Hal ini dapat dilihat dari gambaran sampel formula yang diamati di bawah TEM, partikel memiliki ukuran partikel yang seragam yaitu ukuran antar partikel satu dengan lain tidak berbeda jauh.

Teknik mikroskopis memberikan gambaran yang lebih jelas dan rinci mengenai morfologi struktur nano. Dari hasil pengamatan menggunakan TEM diperoleh bahwa partikel berbentuk bulat (spheris). Bentuk bulat partikel sesuai dengan bentuk bulat pori-pori sel, akan tetapi penyerapan senyawa obat secara invivo adalah dalam bentuk molekul sehingga kafein harus release dari pembawa nanopartikel (Mardiyanto et al., 2018).

Zeta potensial merupakan parameter yang sangat penting untuk memprediksi kestabilan dispersi koloid. Zeta potensial adalah perbedaan potensial antara batas fasa padatan dan cairan, merupakan muatan listrik dari partikel yang tersuspensi dalam cairan. Zeta potensial yang tinggi mencerminkan sediaan yang stabil karena adanya gaya tolak menolak dan stabilisasi dari dispersi nanopartikel sehingga dapat mencegah terjadinya agregasi. Jika nilai zeta potensial kecil, akan terjadi gaya tarik menarik dan dispersi dapat pecah atau berubah menjadi flokulasi (Fonseca-Gomes et al., 2020). Nanopartikel yang memiliki zeta potensial lebih dari $+30 \mathrm{mV}$ atau kurang dari -30 mV dianggap sebagai sistem suspensi koloid stabil (Raval et al., 2018). Dalam percobaan ini diperoleh nilai zeta potensial -13,5 mV dan -12,8 mV. Seperti yang telah diprediksi dalam penelitian ini, 
zeta potensial akan bernilai negatif karena adanya gugus karboksil ( $\left.\mathrm{COO}^{-}\right)$dari polimer PLGA (Fonseca-Gomes et al., 2020).

Ukuran partikel yang diperoleh dari hasil pengamatan menggunakan TEM adalah $200 \mathrm{~nm}$. Hasil ini tidak jauh berbeda dengan hasil pengukuran menggunakan PSA. Pada penelitian ini teknik yang digunakan pada alat PSA adalah Dynamic Light Scattering (DLS). Dari 2 kali pengulangan diperoleh hasil ukuran partikel berturut-turut $183,9 \mathrm{~nm}$ dan 184,7 nm. Dengan membandingkan data DLS dan Transmisi Electron Microscopy (TEM), keadaan agregasi nanopartikel dapat dengan mudah ditentukan. Jika suspensi dalam bentuk unaggregated, maka perbedaan ukuran partikel antara data hasil DLS dan TEM tidak terlalu jauh. Jika suspensi dalam bentuk agregat, maka diameter/ukuran partikel yang diukur dengan DLS jauh lebih besar daripada hasil analisis ukuran TEM (Raval et al., 2018) .
Berdasarkan hal tersebut, maka walaupun nilai zeta potensial yang diperoleh pada penelitian ini belum mendekati -30 mV, namun dari perbandingan ukuran partikel hasil analisis dengan DLS dan TEM dapat disimpulkan bahwa pada sediaan tidak terjadi agregasi artinya sediaan cukup stabil.

Obat yang diformulasi dalam bentuk nanopartikel biasanya berada dalam bentuk inaktif dan memerlukan terjadinya drug release agar dapat bekerja pada jaringan/organ target. Kegagalan dalam pelepasan molekul obat aktif pada site of action adalah salah satu kemungkinan alasan kegagalan formula nanopartikel secara klinis. Perlu dilakukan uji disolusi in vitro untuk melihat pelepasan molekul obat dari preparat nanopartikel dan dengan uji in vivo pada hewan coba dapat dilihat apakah terjadi peningkatan nilai parameter farmakokinetik setelah dilakukan modifikasi pada formula kafein 


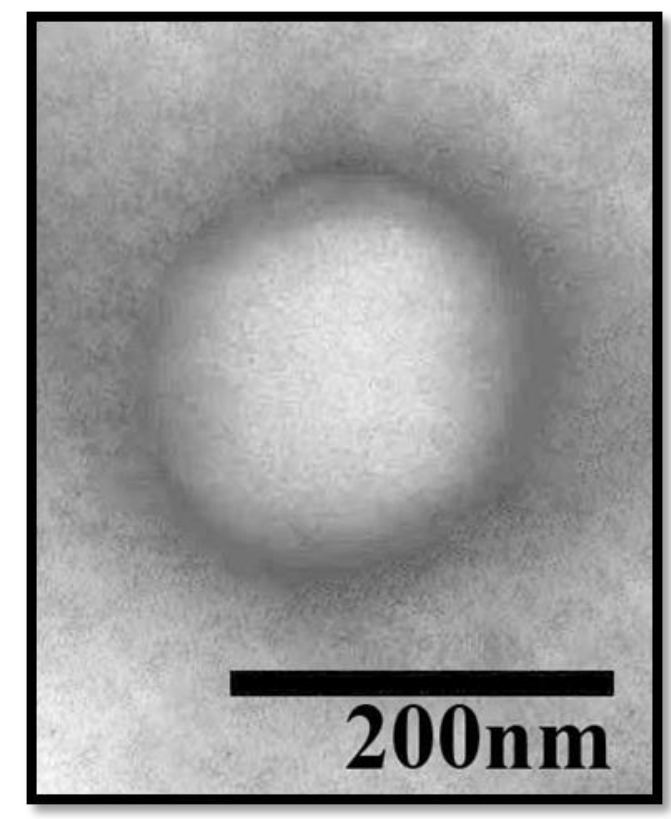

Gambar 4. Ukuran Partikel Kafein dengan pembawa PLGA dilihat menggunakan TEM Jeol jem-1010, 80.0 KV, perbesaran 50.000 x Sumber : Dokumentasi Pribadi, 2021

\section{KESIMPULAN}

Kafein dapat diisolasi dari biji kopi robusta dan hasil identifikasi menunjukkan bahwa kafein yang diperoleh memiliki karakteristik yang mirip dengan kafein standar dan morfologi kristal kafein sesuai dengan yang disebutkan dalam literatur. Kafein dapat diformulasi menjadi preparat nanopartikel menggunakan pembawa PLGA dan PVA sebagai stabilizer dengan metode single emulsion-solvent evaporation. Preparat nanopartikel yang dihasilkan memiliki karakteristik sesuai dengan karakteristik nanopartikel yang dipersyaratkan.

\section{UCAPAN TERIMA KASIH}

Kami mengucapkan terima kasih kepada Laboratorium Bioteknologi dan Laboratorium Mikrobiologi Fakultas
Matematika dan Ilmu Pengetahuan Universitas Sriwijaya, Laboratorium Pengujian Obat, Makanan dan Kosmetika Universitas Islam Indonesia Yogyakarta dan Laboratorium TEM dan Histologi Lembaga Eijkman yang telah membantu dalam karakterisasi preparat nanopartikel.

\section{DAFTAR PUSTAKA}

Ahmad Bhawani, S., Fong, S. S., \& Mohamad Ibrahim, M. N. (2015). Spectrophotometric Analysis of Caffeine. International Journal of Analytical Chemistry, 2015. https://doi.org/10.1155/2015/170 239

Andrén-Sandberg, A. (2016). Caffeine As a Substance for Better Performance. Anti-Doping Library, January.

Castro, E., \& Kumar, A. (2013). Nanoparticles in drug delivery systems. Nanomedicine in Drug Delivery, 1(2), 1-22. https://doi.org/10.1201/b14802

Chaugule, A., Patil, H., Pagariya, S., \& Ingle, P. (2019). Extraction of 
Caffeine. International Journal of Advanced Research in Chemical Science, 6(9), 11-19. https://doi.org/10.20431/23490403.0609002

Danhier, F., Ansorena, E., Silva, J. M., Coco, R., Le Breton, A., \& Préat, V. (2012). PLGA-based nanoparticles: An overview of biomedical applications. Journal of Controlled Release, 161(2), 505-522.

https://doi.org/10.1016/j.jconrel. 2012.01.043

dePaula, J., \& Farah, A. (2019). Caffeine Consumption through Coffee: Content in the Beverage, Metabolism, Health Benefits and Risks. Beverages, 5(2), 37. https://doi.org/10.3390/beverag es5020037

Fauziah, F., Zulharmita, \& Ningsih, W. (2017). Pembuatan kafein benzoat secara semisintetis dari serbuk teh kayu aro. 9(1).

Fonseca-Gomes, J., Loureiro, J. A., Tanqueiro, S. R., Mouro, F. M., Ruivo, P., Carvalho, T., Sebastião, A. M., Diógenes, M. J., \& Pereira, M. C. (2020). In vivo biodistribution and toxicity evaluation of polymeric and lipidbased nanoparticles: A potential approach for chronic diseases treatment. International Journal of Nanomedicine, 15, 8609-8621. https://doi.org/10.2147/IJN.S26 7007

Goldemberg, D. C., Antonio, A. G., Farah, A., \& Maia, L. C. (2014). Coffea canephora: A Promising Natural Anticariogenic Product. A Promising Natural Anticariogenic Product. In Coffee in Health and Disease Prevention. Elsevier Inc. https://doi.org/10.1016/B978-012-409517-5.00069-3

Mardiyanto, M., Fithri, N. A., \& Raefty, W. (2018). Optimasi Formula Submikro Partikel Poly (Lacticco-Glycolic Acid) Pembawa Betametason Valerat dengan Variasi Konsentrasi Poly (Vinyl Alcohol) dan Waktu Sonikasi.
Jurnal Sains Farmasi \& Klinis, 5(1),

55 . https://doi.org/10.25077/jsfk.5.1. 55-65.2018

Nurdiansyah, N. F. (2014). Implementasi Sistem Nilai Cacat Kopi Robusta Hasil Proses Pengolahan (Studi Kasus Pengolahan Metode Semi Basah Di Jember Pengolahan Metode Kering Di Banyuwangi Dan Malang). UNIVERSITAS JEMBER.

Raval, N., Maheshwari, R., Kalyane, D., Youngren-Ortiz, S. R., Chougule, M. B., \& Tekade, R. K. (2018). Importance of physicochemical characterization of nanoparticles in pharmaceutical product development. In Basic Fundamentals of Drug Delivery. Elsevier Inc. https://doi.org/10.1016/B978-o12-817909-3.00010-8

Sarfraz, A., Simo, A., Fenger, R., Christen, W., Rademann, K., Panne, U., \& Emmerling, F. (2012). Morphological diversity of caffeine on surfaces: Needles and hexagons. Crystal Growth and Design, 12(2), 583-588. https://doi.org/10.1021/cg101358 q

Sidiq, A. N. (2018). Uji Profil Farmakokinetik Sediaan Nanopartikel Ramuan Ekstrak Pinang (Areca cathecu), Purwoceng (Pimpinella pruatjan) Dan Ginseng Jawa (Talinum paniculatum) Berefek Afrodisiaka.

Suwiyarsa, I. N., Nuryanti, S., \& Hamzah, B. (2018). Analisis Kadar Kafein dalam Kopi Bubuk Lokal yang Beredar di Kota Palu. Jurnal Akademika Kimia, 7(4), 189. https://doi.org/10.22487/j24775 185.2018.v7.i4.11943

Wilantari, P. D. (2018). Isolasi Kafein Dengan Metode Sublimasi Dari Dengan Fraksi Etil Asetat Serbuk Daun Camelia Sinensis. Jurnal Farmasi Udayana, 8(1), 53. https://doi.org/10.24843/jfu.201 8.v07.io2.po3 
Zarwinda, I., \& Sartika, D. (2019). Pengaruh Suhu Dan Waktu Ekstraksi Terhadap Kafein Dalam Kopi. Lantanida Journal, 6(2), 180.

https://doi.org/10.22373/lj.v6i2. 3811

Zhuang, Y., Shen, H., Yang, F., Wang, X., \& Wu, D. (2016). Synthesis and characterization of PLGA nanoparticle/4-arm-PEG hybrid hydrogels with controlled porous structures. RSC Advances, 6(59), 53804-53812.

https://doi.org/10.1039/c6rao84 o4d

Copyright (c) 2021 Jurnal Mandala Pharmacon Indonesia; This article is an open access article distributed under the terms and conditions of the Creative Commons Attribution License (http://creativecommons.org/licenses/by/4.0/) 